\title{
Neurosensory Hearing Loss in Secondary Adhalinopathy
}

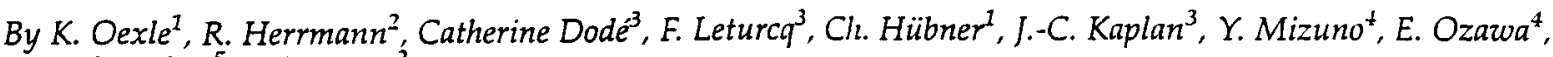 \\ K. P. Campbell ${ }^{5}$ and T. Voit ${ }^{2}$ \\ ${ }^{1}$ Abteilung Leuropädiatrie, Charité, Humboldt-Universität, Berlin, Germany, 'Zentrum für Kinderheilkunde des Universitätsklinikums, \\ Essen, Germany, ${ }^{3}$ Institut National de la Santé et de la Recherche Médicale Unité 129 and Laboratoire de Biochimie Génétique, Centre \\ Hospitalier Universitaire Cochin, Université René Descartes, Paris. France, 'Department of Cell Biology, National Institute of \\ Neuroscience, NCNP, Tokyo, Japan 187, and 'Department of Physiologr' and Biophysics. The University of Iowa College of Medicine, \\ lowa City, Iowa 52242 , USA
}

\begin{abstract}
We report mild-to-moderate neurosensory hearing loss and severe childhood autosomal recessive muscular dystrophy with adhalin-deficiency in two siblings from a Bulgarian sibship of Turkish origin. Vlicrosatellite analysis excluded linkage to the adhalin gene, mutations of which cause limb girdle muscular dystrophy (LG.ID) 2D, but was compatible with linkage to the gene locus of LGVID $2 C$ on chromosome 13q12. Compound heterozygosity of the affected siblings was detected in this chromosomal region. A severe autosomal recessive form of neurosensory deafness has been linked to the same region (locus NSRDi) which is now contained in a $7 \mathrm{MBb}$ YAC contig. Using polymorphic markers and STS PCR primers mapping in this contig, we did not find evidence for major rearrangements in the suspected region. These preliminary findings are not in favor of, but do not completely exclude a contiguous gene syndrome in these cases. Therefore, we consider a potential role of the putative 13q12 gene product and/or adhalin in neurosensory hearing.
\end{abstract}

\section{Key words}

Limb-girdle muscular dystrophy (LGMD) Non-syndromic recessive deafness (NSRD) - Adhalin Dystrophin - Chromosome 13q12

\section{Abbreviations}

DAG: dystrophin-associated glycoprotein

DMD: Duchenne muscular dystrophy

LGMD: limb-girdle muscular dystrophy

NSRD: non-syndromic recessive deafness

STS: sequence-tagged site

\section{Introduction}

X-chromosomal recessive Duchenne muscular dystrophy (DVD) is caused by deficiency of dystrophin, a submembraneous cytoskeletal protein $(17,19)$. Dystrophin is associated with an oligomeric complex of sarcolemmal glycoproteins linking the intracellular actin skeleton with the extracellular matrix $(8,11,12)$. Dystrophin deficiency leads to reduced expression of these dystrophin-associated glycoproteins (DAGs) $(11,23)$. Autosomal recessive limb girdle muscular dystrophy of variable severity is related to the deficiency of adhalin, a $50 \mathrm{kD}$-component of the DAG complex, while dystrophin expression is preserved (22). In some patients LGMID, subsequently termed LGMD 2D, is assoriated with mutations of the adhalin gene on chromosome $17 \mathrm{q}(1,7,27$, 30). However, in some North African patients adhalin-deficient LGMD, subsequently termed LGMD $2 \mathrm{C}$, has been linked to chromosome 13q12 $(4,5,7)$; adhalin-deficiency is supposed to be secondary in these cases.

Genetic markers within the dystrophin gene have been linked to an X-chromosomal, non-syndromic form of neurosensory hearing loss (20) although auditory dysfunction has not been implicated with DND $(2,33)$. Recessive (13) and dominant (9) non-syndromic forms of deafness (NSRD1 locus) were mapped to the $13 q 11$ region in close proximity with the LGMD $2 \mathrm{C}$ locus. In these cases of hearing loss, evidence of muscular dystrophy has not been reported. Here, we describe the combination of neurosensory hearing loss and severe muscular dystrophy due to secondary adhalinopathy in a Bulgarian sibship of Turkish origin. The suspected region was explored with markers and sequence-tagged sites (STSs) included in a recently obtained YAC contig covering the NSRD1 and the LGMD 2C loci (14).

\section{Case report}

\section{Family history}

A neuromuscular disorder or auditory dysfunction did not occur before in this Bulgarian family of Turkish origin. The parents of the affected sibship were not consanguinous. Two brothers were healthy. 
Pattent II-3, night ear frequency $(\mathrm{Hz})$

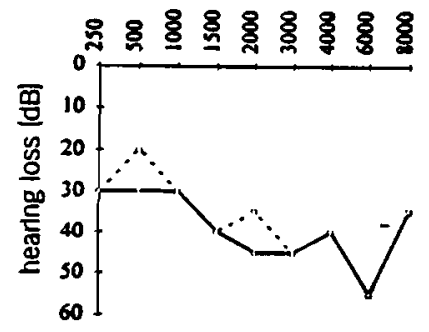

Patlent II-3. left ear frequency $|\mathrm{Hz}|$

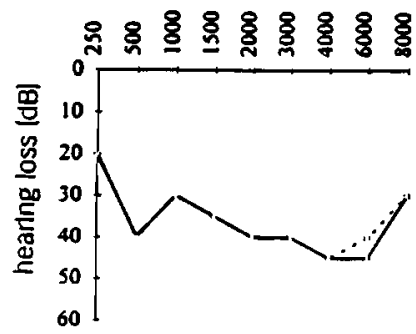

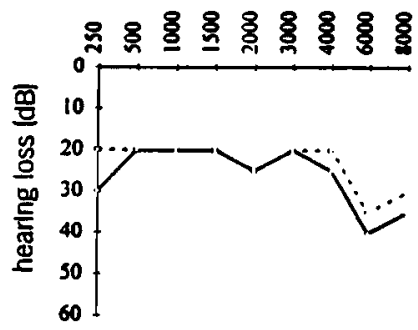

Pattent li-2, right ear frequency $[\mathrm{Hz}$

Pattent II-2, left ear frequency $[\mathrm{Hz}]$

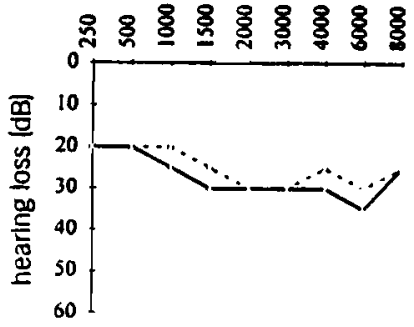

Fig. 1 Pure tone threshold audiograms of the affected siblings II-2 and $\|-3$ tested by air $\longrightarrow$ and bone $(----\mid$ conduction of sound.

\section{Affected sibship}

Pre- and immediate postnatal development was uneventful. Early motor milestones were reached in time. However, the parents reported that first signs of muscular weakness appeared during the following year in both cases, and that progressive deterioration occurred at the age of 9 in the girl (Patient II-2) and at the age of 7 in the boy (Patient II-3). Aged 12 yrs (Patient II-2) and 10 yrs (Patient II-3) at the time of our examination both had a waddling gait. They were not able to stand up from a sitting position. The degree of muscular weakness was similar in both patients. Marginal calf enlargement possibly was non-specific and due to generalized adiposity. There were no joint contractures. Both patients suffered from planovalgus deformity of the feet. There was no evidence of cardiomyopathy by echocardiography. Intelligence was normal. Activity of serum creatin kinase was $7840 \mathrm{U} / \mathrm{A}$ in the boy and $11557 \mathrm{U} / \mathrm{l}$ in the girl.

Both siblings suffered from hearing loss which had not been detected before our examination. Hearing loss was slightly more pronounced at higher frequencies (Fig. 1). Similar results of air- and bone-conduction tests indicated a neurosensory disturbance. The boy (max. loss of $55 \mathrm{~dB}$ at 6 $\mathrm{kHz}$ ) was more severely affected than his sister (max. loss of 40 $\mathrm{dB}$ at $6 \mathrm{kHz}$ ). There was no history of damage due to excessive noise, of sudden hearing loss after an infection, or of potentially harmful drug intake.

\section{Methods}

\section{Immunofluorescence}

Five $\mu \mathrm{m}$ cryosections of the muscle specimens were placed on Poly-L-Lysine (Sigma, St. Louis, US) coated

slides and incubated with the primary antibody in PBS, containing $1 \% \mathrm{BSA}$, for $1.5 \mathrm{~h}$ at $37^{\circ} \mathrm{C}$, followed by the corresponding secondary antibodies for $1 / 2 \mathrm{~h}$ at $37^{\circ} \mathrm{C}$, visualized (except for A3b) with streptavidin-Texas Red (Amersham, Braunschweig, FRG) 1:200 for $3 / 4 \mathrm{~h}$, and photographed on a Zeiss III RS photomicroscope equipped for epifluorescence. The following antibodies were used: mAb against adhalin (22) 1:2, followed by goat anti-mouse IgG1 (Amersham) 1:200; mAb against 35 DAG (36) $1: 8$, and mAbs against $\beta$-dystroglycan, spectrin and dys-2 (all from Novocastra, Newcastle upon Tyne, UK) 1:100, followed by sheep anti-mouse Ig (Amersham) 1:200; mAb antilaminin $\alpha_{2}$ 1:1000 (Gibko, Eggenstein, FRG), followed by sheep anti-mouse Ig 1:200 (Amersham); $\mathrm{mAb}$ anti-laminin $\beta_{1}$ (Gibko) 1:1000, followed by goat antimouse IgG1 (Amersham); mab anti-laminin $\gamma_{1}$ (Gibko) 1:200, followed by goat anti-mouse IgG2a (Amersham) 1:200; pAb against $\mathrm{A} 3 \mathrm{~b}$ [37] 1:100, followed by dichlorotriazinyl aminofluorescein-labelled goat $F\left(a b^{\prime}\right) 2$ anti-guinea-pig IgG (Chemicon, Temecula. CA, US) 1:200.

\section{DNA analysis}

Linkage analysis was performed using seven microsatellites on chromosome 13 covering a distance of about $6 \mathrm{c.V}$ in the 13q11-q12.1 region: D13S292 (AF:M351xd9), D13S283 (AF.1296vb9), D13S290 (AF.1323vh1) (15); D13S141, D13S143 (26); D13S115 (18); D13S221 (AFW1248wc1) (35). For the chromosome 17q21 region we used one microsatellite located within the intron 6 of the adhalin gene (D17S1319) (1) and the extragenic microsatellites D17S791 (AFY1150xd12) and D17S941 (AF.1269xd1) (15).

Deletions in the $13 q 11-q 12$ region were searched by PCR using six STSs (D13S1115, D13S1122, D13S1123, D13S1124, D13S1125, D13S1128) comprised in a $7 \mathrm{Mb}$ YAC contig established between D13S143 and D13S292 (14).

\section{Audiometry}

Unspecific disturbances of the middle ear were excluded by local inspection. Subjective hearing capacity was tested by pure tone threshold audiometry. Both air and bone conduction of sound were used for testing.

\section{Results}

\section{Muscle immunohistology}

of both affected siblings showed preserved or marginally reduced expression of dystrophin (Fig. 2), $\beta$-dystroglycan, laminins $\alpha_{2}, \beta_{1}, \gamma_{1}$, and spectrin (not shown). Due to the marked dystrophic changes of the specimens, fibre surface staining was irregular in some places. In contrast, adhalin (50 DAG or $\alpha$-sarcoglycan) was clearly reduced, with a few traces of immunoreactive material detectable on some fibres (Fig. 2). Moreover, a $35 \mathrm{kD}$ dystrophin-associated protein detected with MA4-2 antibody in normal muscle (36) was lacking completely, and $\mathrm{A} 3 \mathrm{~b}$ was detectable only in traces (Fig. 2). 

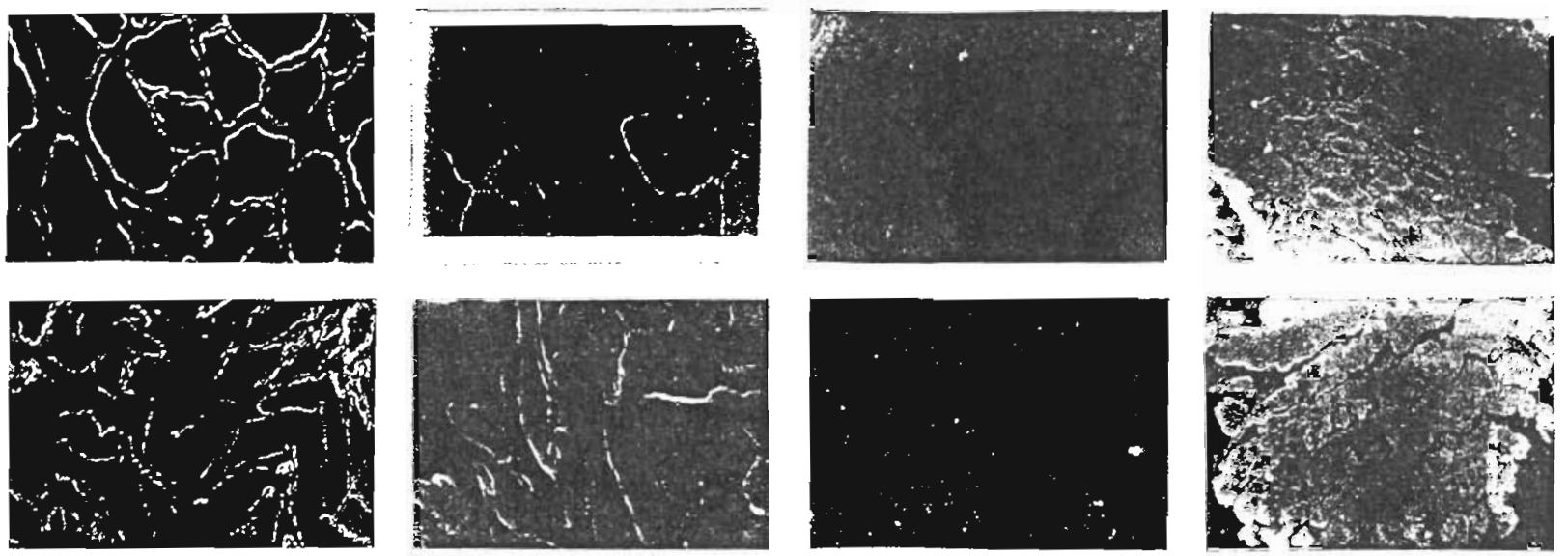

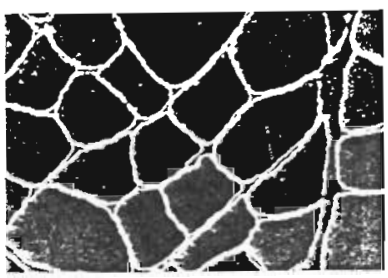

dystrophin

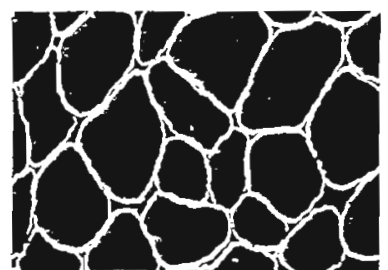

$50 \mathrm{DAG}$

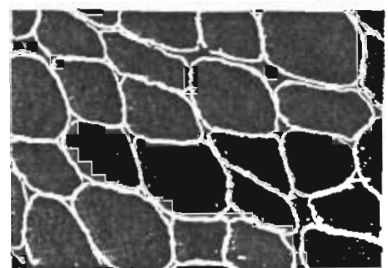

$35 \mathrm{DAG}$

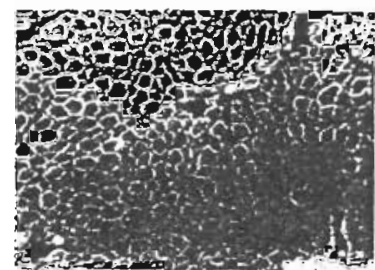

A3b

Fig. 2 Cryosections of $\mathrm{m}$. vasius lateralis labeled for dystrophin and the dystrophin-associated prote!ns that belong to the sarcoglycan complex. Comparison between the affecied siblings and a normal control.

\section{Genetic linkage analysis}

Microsateilite markers of chromosome 17q21 including an intragenic markier of the adhalin gene (D17S1319) (1) indicated that the affected siblings share only one common allele of the adhalin gene. Therefore, linkage of recessive hearing loss or recessive muscular dystrophy to a mutation of this gene is most unlikel. Allelic distribution of $13 q 12$-micro- satellites was identical in both siblings and different in three unaffected family members. Hence, microsatelite data were compatible with secondary adhalin-deficiency related to chromosome 13q12 (Fig. 3). The six STSs scattered on the YAC contig gave a nomal pattern aiter PCR amplification, suggesting the absence of large-scale deletion or rearargement (not shown).

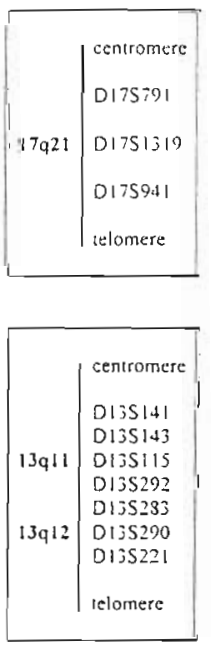

Fig. 3 Allellc distribution of $17 \mathrm{q} 21$ and $13 \mathrm{q} 11-$ a12 microsateliltes in the affected siblings (II-2. II-3I. one healthy brother and both parents. D17S791, -1319 and -941 (from top to bottom] were used as 17q-markers, DL3S141, -143,-115, -292. $-283,-290,-221$ as $13 q$-markers. 


\section{Discussion}

The relation of muscular dystrophy in Patients II-2 and II-3 to adhalinopathy was indicated by markedly reduced expression of adhalin (50 DAG) and complete deficiency of a $35 \mathrm{kD}$ dystrophin-associated protein as opposed to the preserved expression of dystrophin, $\beta$-dystroglycan (43 DAG) and laminin $(22,24)$. Moreover, A3b labeling was vastly decreased revealing a generally reduced expression of the sarcoglycan complex. The sarcoglycan complex consists of dystrophin-associated and membrane-integrated proteins that do not seem to bind directly to dystrophin or laminin (24). Hence, the effects of adhalin-deficiency on sarcolemmal integrity and/or bridging between intra- and extracellular matrices deserve further evaluation.

Adhalinopathy of our patients was shown to be secondary by exclusion of a linkage with the adhalin gene locus $(1,30)$. Secondary adhalin deficiency in LGMD $2 \mathrm{C}$ has been linked to chromosome $13 q 12(4,5)$. Indeed, allelic distribution of $13 q 12$-microsatellites was identical in the affected siblings but different in other family members, consistent with a linkage of LGMD and hearing loss in our patients to this chromosomal region. The existence of a third gene locus of adhalinopathy cannot be ruled out, however. Microsatellite markers also indicated that our patients are compound heterozygotes, suggesting different mutations on each chromosome. In addition, deletions or large-scale rearrangements of the $13 q 12$ gene locus have not been found. We conclude that the combination of hearing loss and muscular dystrophy in our patients is not likely due to a contiguous gene syndrome.

Neurosensory hearing loss is associated with distinct myopathies like MELA-AS-mitochondriopathy (16), myotonic dystrophy (32) and facioscapulohumeral dystrophy (6, $33)$. However, hearing impairment has not been implicated with DMD and DMD-like muscular dystrophies $(2,33)$. Nonetheless, a non-syndromic X-chromosomal form of sensorineural hearing loss maps to markers within the dystrophin gene (20). Furthermore, a dominant form of deafness (21) maps to the same region of chromosome 5 as a dominant form of limbgirdle muscular dystrophy (LGMD 1A) (7). Likewise, the 13q11-q12 region, where LGMD 2C maps, also contains a locus for recessive (13) and dominant (9) forms of deafness. However, neither has muscular dystrophy been reported in patients with these forms of deafness nor has hearing loss been described in LGMD $1 \mathrm{~A}$ or $2 \mathrm{C}(4,5,7,13,23,38)$. We show that LGMD with secondary adhalin deficiency may be associated with mild-to-moderate neurosensory hearing loss but we cannot completely exclude a coincidental combination of these disorders. In view of clinically silent electroretinographic abnormalities in DMD-patients (28) Lalwani et al (20) recommended elaborate audiological testing of muscular dystrophy patients. Our findings support this recommendation. Vice versa, we emphasize the equal necessity of appropriate (laboratory) analysis and report of muscle status including $\mathrm{CK}$ assessment in hereditary forms of hearing loss.

Defects of proteins that interact with the cytoskeleton may cause hearing impairment as has been shown in Usher syndrome type 1 (34). Hearing loss in our LGMD patients is compatible with a function of the putative 13q12 gene product and/or adhalin in the inner ear. However, to our knowledge expression of dystrophin and DAGs in the inner ear has not been investigated as yet $(3,10,25,29,31,39)$.

\section{Addendum}

Recently, dystrophin was detected in the hair cells of the cochlea (Dodson et al, J. Neurocytol. 24 [1995] $625-632$ ).

\section{Acknowledgement}

We thank $A$. Lauterbach for skillful technical assistance. This study was supported by a grant (Vo 392/2-3) from the Deutsche Forschungsgemeinschaft (DFG), and by the Association Française contre les Myopathies (AFM). K. P. C. is an Investigator of the Howard Hughes Medical Institute.

\section{References}

${ }^{1}$ Allamand, V., F. Leturcq, F. Piccolo, M. Jeanpierre, K. Azibi, S. L. Roberds et al: Adhalin gene polymorphism. Hum. Wol. Genet. 3 (1994) 2269

2 Allen, N. R.: Hearing acuity in patients with muscular dystrophy. Dev. Med. Child Neurol. 15 (1973) 500-505

3 Anniko, M., W. Arnold, T. Stigbrand, A. Ström: The human spiral ganglion. ORL J. Otorhinolaryngol. Relat. Spec. 57 (1995) 68-77

+ Azibi, K., L. Bachner, J. S. Beckmann, K. Matsumura, E. Hamouda, M. Chaouch et al: Severe childhood autosomal recessive muscular dystrophy with the deficiency of the $50 \mathrm{kDa}$ dystrophin-associated glycoprotein maps to chromosome 13q12. Hum. Mol. Genet. 2 (1993) 1423-1428

${ }^{5}$ Ben Othmane, K., M. Ben Hamida, M. A. Pericak-Vance, C. Ben Hamida, S. Blel, S. C. Carter et al: Linkage of Tunisian autosomal recessive Duchenne-like muscular dystrophy to the pericentromeric region of chromosome 13q. Nature Genet. 2 (1992) 315-317

${ }^{6}$ Brouwer, O. F., G. W. Padberg, C. Wijmenga, R. R. Frants: Facioscapulohumeral muscular dystrophy in early childhood. Arch. Neurol. 51 (1994) 387-394

7 Bushby, K., J. S. Beckmann: Report on the 30th and 31st ENMC International Workshops on the limb-girdle muscular dystrophies: proposal for a new nomenclature. Neuromusc. Disord. 5 (1995) 337-343

8 Campbell, K. P., S. D. Kahl: Association of dystrophin and an integral membrane glycoprotein. Nature 338 (1989) 259-262

${ }^{9}$ Chaib, H., G. Lina-Granade, P. Guilford, H. Plauchu, J. Levilliers. A. Morgon, C. Petit: A gene responsible for a dominant form of neurosensory nonsyndromic deafness maps to the NSRD 1 recessive deafness gene interval. Hum. Mol. Genet. 3 (1994) 2219-2222

10 Drenckhahn, D., K. Engel, D. Höfer, C. Merte, L. Tilney, M. Tilney: Three different actin filament assemblies occur in every hair cell: Each contains a specific actin crossinking protein. J. Cell Biol. 112 (1991) 641-651

11 Eroasti, J. M., K. Ohlendieck, S. D. Kahl, M. G. Gaver, K. P. Campbell: Deficiency of a glycoprotein component of the dystrophin complex in dystrophic muscle. Nature 345 (1990) 315-319

12 Eroasti, J. M., K. P. Campbell: A role for the dystrophin-glycoprotein complex as a transmembrane linker between laminin and actin. J. Cell Biol. 122 (1993) 809-823

13 Guilford, P., 5. Ben Arab, S. Blanchard, J. Levilliers, J. Weissenbach, A. Belkahia, C. Petit: A non-syndromic form of neurosensory, recessive deafness maps to the pericentromeric region of chromosome 13q. Nature Genet. 6 (1994) 24-28

14 Guilford, P., C. Dodé, F. Crozet, S. Blanchard, H. Chaib, J. Levilliers et al: A YAC contig and an EST map in the pericentrometric region of chromosome 13 surrounding the loci for neurosensory non-syndromic deafness (DNFB1 and DFNA3) and the limb-girdle muscular dystrophy type 2C (LGMD 2C). Genomics (1995) (in press) 
15 Gyapay, G., I. Morissette, A. Vignal, C. Dib. C. Fizames, P. Millasseau et al: The 1993-94 Généthon human genetic linkage map. Nature Genet. 7 (1994) 246-339.

${ }^{16}$ Hirano, M., E. Ricci, R. Koenigsberger, R. Defendini, S. G. Pavlakis, D. C. DeVivo et al: MELAS: an original case and clinical criteria for diagnosis. Neuromusc. Disord. 2 (1992) 125-135

${ }^{17}$ Hoffman, E. P., R. H. Jr. Brown, L. M. Kunkel: Dystrophin: the protein product of the Duchenne muscular dystrophy locus. Cell 51 (1987) 919928

${ }^{18}$ Hudson, T. J., M. Engelstein, M. K. Lee, E. C. Ho, M. J. Rubenfield, C. $P$. Adams et al: Isolation and chromosomal assignment of 100 highly informative human simple sequence repeat polymorphisms. Genomics 13 (1992) 622-629

${ }^{19}$ Koenig, M., A. P. Monaco, L. M. Kunkel: The complete sequence of dystrophin predicts a rod-shaped cytoskeletal protein. Cell 53 (1988) 219-228

20 Lalwani, A. K., J. R. Brister, J. Fex, K. M. Grundfast, A. T. Pikus, B. Ploplis et al: A new nonsyndromic $X$-linked sensorineural hearing impairment linked to Xp21.2. Am. J. Hum. Genet. 55 (1994) 685-694

21 Leon, P. E., H. Raventos, E. Lynch, J. Morrow, M.-C. King: The gene for an inherited form of deafness maps to chromosome 5q31. Proc. Natl. Acad. Sci U.S.A. 89 (1992) $5181-\overline{5} 184$

22 Matsumura, K., F. M. S. Tomé, H. Collin, K. Azibi, M. Chaouch, I.-C. Kaplan et al: Deficiency of the 50K dystrophin-associated glycoprotein in severe childhood autosomal recessive muscular dystrophy. Nature 359 (1992) 320-322

23 Matsumura, K., K. P. Campbell: Dystrophin-glycoprotein complex: its role in the molecular pathogenesis of muscular dystrophies. .luscle Nerre 17 (1994) $2-15$

${ }^{24}$ Mizuno, Y., S. Nogushi, H. Yamamoto, M. Yoshida, A. Suzuki, Y. Hagiwara et al: Selective defect of sarcoglycan complex in severe child. hood autosomal recessive muscular dystrophy muscle. Biochem. Biophys. Res. Commun. 203 (1994) 979-983

${ }^{25}$ Nishizaki, K., S.-l. Usami, M. Anniko, W. Arnold: Comparative cytoskeletal analyses of the inner ear in man and the squirrel monkey. ORL J. Otorhinolaryngol. Relat. Spec. 57 (1995) 87-93

${ }^{26}$ Petrukhin, K. E., M. C. Speer, E. Cayanis, M. Bonaldo, U. Tantravahi, $M$. B. Soares et al: A microsatellite genetic linkage map of human chromosome 13. Genomics 15 (1993) 76-85

27 Piccolo, F., S. L. Roberds, M. Jeanpierre, F. Leturcq, K. Azibi, C. Beldjord et al: Primary adhalinopathy: a common cause of autosomal recessive muscular dystrophy of variable severity. Nature Genet. 10 (1995) 243245

28 Pillers, D. M., D. E. Bulman, R. G. Weleber, D. A. Sigesmund, M. A. Musarella, B. R. Powell et al: Dystrophin expression in the human retina is required for normal function as defined by electroretinography. Nature Genet. 4 (1993) 82-86
29, Roberds, S. L., R. D. Anderson, O. lbraghimov-Beskrovnaya, K. P. Campbell: Primary structure and muscle-specific expression of the 50 $\mathrm{kDa}$ dystrophin-associated glycoprotein (adhalin). J. Biol. Chem. 268 (1993) 23739-23742

30 Roberds, S. L., F. Leturca, V. Allamand, F. Piccolo, M. Jeanpierre, R. D. Anderson et al: Missense mutations in the adhalin gene linked to autosomal recessive muscular dystrophy. Cell 78 (1994) 625-633

31 Slepecky, N. B., M. Ulfendahl: Actin-binding and microtubule-associated proteins in the organ of Corti. Hear. Res. 57 (1992) 201-215

32 Verhagen, W. I. M., J. P. ter Bruggen, P. L. M. Huygen: Oculomotor, auditory, and vestibular responses in myotonic dystrophy. Arch. Neurol. 49 (1992) 954-960

33 Voit, T., A. Lamprecht, H.-G. Lenard, H. H. Goebel: Hearing loss in facioscapulohumeral dystrophy. Eur. J. Pediatr. 145 (1986) 280-285

3 Weil, D., S. Blanchard, I. Kaplan, P. Guilford, F. Gibson, J. Walsh et al: Defective myosin VIA gene responsible for Usher syndrome type $1 \mathrm{~B}$. Nature 374 (1995) 60-61

35 Weissenbach, I., G. Gyapay, C. Dib, A. Vignal, J. Morrissette, P. Millasseau et al: A second-generation linkage map of the human genome. Vature 350 (1992) 794-801

36 Yamamoto, H., Y. Mizuno, K. Hayashi, I. Nonaka, M. Yoshida, E. Ozawua: Expression of dystrophin-associated protein 35DAG (A4) and 50 D.AG (A2) is confined to striated muscles. J. Biochem. (Tokyo) 115 (1994) 162-167

37 Yositida. M., A. Suzuki, H. Yanamoto, S. Noguchi, Y. Mizuno, E. Ozawa: Dissociation of the complex of dystrophin and its associated proteins into several unique groups by $n$-octyl $\beta$-D-glucoside. Eur. J. Biochem. 222 (1994) 1055-1061

ss Zatz, M., K. Matsumura, M. Vainzof, M. R. Passos-Bueno, R. C. M. Pavanello, S. K. Marie, K. P. Campbell: Assessment of the $50-\mathrm{kDa}$ dystrophin-associated glycoprotein in Brazilian patients with severe childhood autosomal recessive muscular dystrophy. J. Neurol Sci. 123 (1994) $122-128$

39 Zine, E.-A., R. Romand: Expression of alpha-actinin in the stereocilia of hair cells of the inner ear: immunohistochemical localization. Neuroreport 4 (1993) $1350-1352$

Dr. med. K. Oexle

Neuropädiatrie, Kinderklinik der Charité

Humboldt-Universität

Schumannstr. 20/21

D-10098 Berlin

Germany 